\title{
ИЗУЧЕНИЕ КАНЦЕРОГЕННОЙ ЗАГРЯЗНЕННОСТИ ВОД БАЛТИЙСКОГО МОРЯ
}

При разработке проблемы защиты окружающей среды от загрязнения все большее внимание специалистов привлекает вопрос охраны тидросферы от загрязнения канцерогенными веществами, в частности, полициклическими ароматическими углеводородами (ПАУ) - продуктами термического воздействия на органическое вещество. ПАУ - универсалыные загрязнители среды, поскольку они присутствуют во всех продуктах и отходах человеческой деятельности, промышленных и бытовых выбросах. Из числа изученных в настоящее время примерно 600 видов ПАУ наиболее распространен, стабилен ко всем видам воздействий и сильно канцерогенен бенз(а) пирен (БП), расоматриваемый многими исследователями $\left[{ }^{1,2}\right]$ как индикатор, по содержанию которого считается возможным оценить уровень канцерогенной запрязненности среды. БІІ присутствует практически во всех природных объектах, вне зависимости от их территориального расположения, и таким образом в окружающей среде имеется его некоторое фоновое содержание. В районах же с интенсивной хозяйственной деятельностью количество БП возрастает по сравнению с фоновым в десятки, сотни и даже тысячи раз, что может представлять опасность для здоровья человека. Учитывая сложную экологическую обстановку, складывающуюся в настоящее время в регионе Балтийского моря, постановка комплексного исследования его вод, грунтов и водных объектов для определения содержания БП весьма актуальна.

Существенное влияние на физнологические свойства ПАУ могут оказывать и другие биологически активные вещества, сопутствующие им в составе загрязнений ореды. В особенности это относится к синтетическим поверхностно-активным веществам (СПАВ), достаточно широко распространенным в гидросфере и грунтовых отложениях водоемов и способствующим повышению растворимости БП в воде [3,4]. Поэтому наряду с распространением БП мы изучали и количество анионных СПАВ (наиболее широко представленных в нашем регионе) в воде и донных отложениях. Накопление данных, полученных при таком комплексном исследовании, и обеспечение статистически достоверных результатов должны быть основой расчетов при моделировании процессов превращения канцерогенных загрязнений в экосистеме Балтийского моря.

На первом этапе работ соопветствующие образцы для изучения были отобраны в двух экспедициях научно-исследовательского судна «АюДаг» Академии наук Эстонской ССР в апреле-мае и октябре-ноябре 1979 г. на станциях, расположенных в Финском и Гданьском заливах, в центральной части Балтики - от устья Финского залива до Датских проливов и в проливе Скагеррак (см. рисунок). Изложение и обсуждение результатов данного этапа исследований предваряется описанием использованной методики изучения проб и определения в них БП и a-СПАВ. 
ривали досуха. Пробу растворяли в 2 мл н-октана. Поскольку экстракты содержали значительное количество примесных органических веществ, для получения спектрально-чистой фракции БП большинство образцов пришлось подвергнуть повторному хроматографическому разделению, в качестве сольвента использовали смесь петролейного эфира $\left(\right.$ фракция $\left.40-70^{\circ}\right)$ и хлороформа в объемном соотношении $9: 1$.

Қоличественное определение содержания БП, растворенного в октане, проводили спектрально-флуоресцентным методом с использованием эффекта Шпольского при температуре кипения жидкого азота на спектрографе ДФС-12 по методике [5], в упрощенном варианте, разработанном в Институте химии АН ЭССР.

К октановому раствору пробы $(0,5 \mu \Omega)$ прибавляли 0,5 м стандартного раствора 1,12-бензперилена в н-октане с концентрацией $10^{-7}$ 2/мл. Стеклянную кювету с исследуемым раствором помещали в сосуд Дюара с жидким азотом. Фиксировали интенсивность флуоресценции 1,12-бензперилена $(\lambda=419,5$ нм) и БП $(\lambda=403$ нм). Количество БП определяли по калибровочной кривой для функции $\lg \left(I_{\text {БП }} / I_{\mathrm{CT}}\right)=f(\lg C)$, концентрацию $а$-СПАВ в воде - с красителемазуром по методике [6], в модернизированном варианте [7]. Количество $a$-СПАВ в донных отложениях определяли колориметрически с метиленовым синим [ $\left.{ }^{8}\right]$ из водного экстракта после-предварительного $(20-24 u)$ замачивания 10 г пробы, с последующей экстракцией (20 ч) в приборе Сокслета.

\section{Полученные результаты и их обсуждение}

Загрязненность воды Балтийского моря БП в весенний и осенний периоды 1979 г. оказалась незначительной и в ореднем находилась на фоновом уровне, значительно меньшем принятой у нас в стране ПДК $(5 \mathrm{~Hz} / \Omega)$. Так, в апреле-мае среднее количество БП в воде составляло 0,66 нг/л (результат исследования 75 проб) с пределами колебаний $0,1-10,5$ нг/л. Концентрация БП в поверхностном слое воды была более высокой (в среднем 0,9 на/ $)$ ), чем в придонных слоях соответственно 0,5 на/л. При этом не было обнаружено значительных колебаний уровня загрязненности БП по всей исследованной нами акватории. В октябре-ноябре содержание БП в воде снизилось в ореднем до $0,16 \mathrm{\mu г/ \Omega}$ (изучены 74 пробы) при колебании его в пределах $0,03-0,52$ нг/ $\Omega$, причем различия в данных для поверхностного и более глубоких слоев практически не наблюдалось - соответствующие средние показатели составляют 0,2 и 0,15 нг/л. Таким образом, полученные данные (см. также []) о загрязненности вод Балтийского моря БП можно оценить как благоприятные.

Однако анализ результатов исследования образцов донных отложений, отобранных в октябре-ноябре 1979 г., позволяющий судить о картине запрязненности в течение более длительного времени, позволяет несколько дифференцировать ее.

Результаты анализа 24 образцов донных отложений графически представлены на рисунке. Среднее количество БП в пробах составляет 9,5 $\mu 2 / \kappa 2$ при следующей встречаемости концентраций:

\begin{tabular}{cc}
$\mu z / \kappa г$ & $\%$ \\
\hline $0-3,0$ & 20,8 \\
$3-10$ & 29,2 \\
$10-20$ & 33,3 \\
свыше 20 & 16,7
\end{tabular}

Коэффициент накопления (грунт-вода) составлял в среднем 58600. 
Содержание БП в пробах планктона

из Балтийского моря

(октябрь-ноябрь 1979 г.)

\begin{tabular}{|c|c|c|}
\hline $\begin{array}{l}\text { Номер } \\
\text { станции }\end{array}$ & $\begin{array}{c}\text { Содержание БП, } \\
\text { ㄹ/ке сухого } \\
\text { вещества }\end{array}$ & $\begin{array}{l}\text { Коэффициент } \\
\text { накопления БП, } \\
\text { планктон-вода }\end{array}$ \\
\hline $\begin{array}{r}3 \\
4 \\
10 \\
11 \\
15\end{array}$ & $\begin{array}{r}4,3 \\
44,9 \\
17,1 \\
3,1 \\
1,8\end{array}$ & $\begin{array}{r}28700 \\
748000 \\
74500 \\
14800 \\
4700\end{array}$ \\
\hline
\end{tabular}

Все это свидетельствует о наличии стабильного, но превышающего фоновый, уровня запрязненности трунта БП, а также о существовании источника вторичного загрязнения вод. Содержание БП в грунтах, отобранных на различных участках акватории Балтийского моря, подвержено значительным колебаниям и ощутимо выше в районах с интенсивным судоходством и хозяйственной деятельностью. Так, в Финском заливе количество БП в прунтах в среднем составляет $10,4 \mu z / \kappa 2$,
в Гданьском заливе 17,2 ㄹ/к2, а в центральной Балтике только заливе количество БП в прунтах в среднем составляет $10,4 \mu z / \kappa 2$,
в Гданьском заливе 17,2 ㄹ/к2, а в центральной Балтике только $6,0 \mu 2 / \kappa 2$.

Результаты, полученные при анализе образцов, взятых на станции № 10 в вертикальном (высота 60 cм) разрезе, свидетельспвуют о том, что БП концентрируется в значительном количестве во всем верхнем слое, толщиной 12 cм, где его содержание составляет $6,2 \mu 2 / \kappa 2$, в то время как в более глубоких слоях количество БП практически не изменяется с уходом в глубину. Эту концентрацию, равную $0,6-0,9 \mu 2 / \kappa 2$, следует, очевидно, рассматривать как естественный фон для данного района. Мы исследовали также планктон, отобранный в Финском заливе и в централыной Балтике. Он представляет собой смесь фито- и зоопланктона с преобладанием первого из них в образцах, отобранных в Финском заливе, а второго - в центральной Балтике. Результаты эпределения содержания БП в планктоне представлены в таблице.

Поскольку планктон - объект питания для многих гидробионтов, юлученные данные представляются достойными внимания.

Параллелыно с определением содержания БП в водных растворах мы предприняли попытку уточнить и количество $a$-СПАВ (ПДК $100 \mu 2 / \Omega)$, для чего исследовали 74 пробы воды и 22 пробы грунта. Обнаружена следующая встречаемость концентраций $a$-СПАВ:

в грунте

в воде

\begin{tabular}{|c|c|c|c|}
\hline$\mu z / \kappa z$ & $\%$ & $\mu 2 / \kappa 2$ & $1 \%$ \\
\hline $\begin{array}{r}50-100 \\
100-150 \\
150-200\end{array}$ & $\begin{array}{l}31,1 \\
48,6 \\
20,3\end{array}$ & $\begin{array}{c}0-2 \\
2-4 \\
4-6 \\
\text { свыше } 6\end{array}$ & $\begin{array}{r}22,7 \\
54,5 \\
13,6 \\
9,2\end{array}$ \\
\hline
\end{tabular}

Как видно, содержание $а$-СПАВ в грунтах значительно превышает их содержание в воде. Средний коэффициент их накопления в прунтах равен 27,1. Таким образом, поверхностно-активные вещества, обладающие высокой сорбционной способностью, аккумулируются в донных отложениях, которые, в свою очередь, могут обусловить вторичное загрязнение гидросферы.

Поскольку общепринятый в настоящее время метод определения a-СПАВ (по комплексообразованию с красителем) страдает рядом недостатков и обычно дает некоторое завышение результатов, в особенности, при анализах морской воды, полученные нами и приведенные в статье данные о содержании $a$-СПАВ в Балтике имеют пока ориентировочный характер. 


\section{Выводы}

1. Проведенное исследование показывает, что содержание БП в воде Балтийского моря незначительно (много меньше ПДК), причем отмечается несколько более высокий его уровень в поверхностных слоях по оравнению с придонными. Кроме того оказалось, что БП способен накапливаться в довольно больших количествах в донных отложениях.

2. Определено, что в планктоне скопление БП более значительно, чем в воде, что говорит о способности данных гидробионтов к его аккумулированию.

3. Установлено, что содержание $a$-СПАВ в грунтах значительно превышает их содержание в воде.

\section{Л ИТЕРА Т У Р А}

1. Andelma n, I. B., Suess, M. I. Polynuclear aromatic hydrocarbons in water environment. - Bull. Org. mond. Sant, 1970, v. 43, p. 479-508.

2. Ш а б а д Л. М. О циркуляции канщерогенов в окружающей среде. М., 1973.

3. Ильн ицки й А. П., Е ршов а К. П. Некоторые факторы, влияющие на растворимость ПАВ и фенолов. - Вопр. онкологии, 1970, т. 16, № 8, с. 86-87.

4. Пылева 3. А., Саутин А. И., Костродымова Г. М., Воронин В. М. Об активирующем действии сульфанола НП-3 на экспериментальный химнческий канцерогенез. - В сб.: Гигиенические аспекты охраны окружающей среды, 1976, М., вып. 4.

5. Федосеев Г. Е., Хесин а А. Я. Использование квазилинейчатых спектров люминесценции для количественного определения ряда полициклических углеводородов. - Ж. приклад. спектроскопии, 1968 , т. 9, с. $282-283$.

6. Л ейте В. Определение органических загрязнений питьевых природных и сточных вод. М., 1975 , с. 199.

7. Векслер В. И., Деева В. Е., Маркович А. В., Мельтева Н. Н., Прох оренко Л. Г. Усовершенствованный метод определения анионных поверх ностных веществ. - Гиг. и санит., 1972, № 5, с. 63-66.

8. Унифицированные методы анализа вод. М., с. 348-350.

9. Gubergrits, M., Kirso, U., Kuiv, K. Benso(a)püreen Läänemere vees. Изв. АН ЭССР. Хим., 1979 , т. 28 , № 3 , с. $222-223$.

Институт химии
Академии наук Эстонской ССР

M. GUBERGRITS, K. KUIV,

Marina TRAPIDO, V. TSEKULAJEV

\section{LÄANEMERE KANTSEROGEENNE SAASTATUS}

Läänemere saastatus benso(a)püreeniga (BP) osutus 1979. aastal küllalt väikeseks ja oli oluliselt allpool NSV Liidus kehtivaid piirnorme. Seejuures oli BP sisaldus vee pindmistes kihtides mōneti kōrgem kui pōhjakihtides. Ka pōhjasetetes oli see suhteliselt suur, samuti on rohkesti BP-d planktonis. On saadud esialgseid andmeid anioonaktiivsete ainete sisalduse kohta vees ja pöhjasetetes (viimastes on see kümneid kordi suurem kui vees).

M. GUBERGRITS, K. KUIV, Marina TRAPIDO, V. TCHEKULAYEV

\section{CARCINOGENIC POLLUTION OF THE BALTIC SEA}

In 1979 the pollution of the Baltic with benzo(a)pyrene (BP) proved to be rather inconsiderable, being below the maximum permissible concentration accepted in the Soviet Union. At that, in the surficial water layers, the content of BP was relatively higher than in the bottom ones, and it was also abundant in the plankton. Preliminary data have been obtained on the content of anion-active matter in the water and in the bottom sediments (in the latter it proved to be considerably higher than in the water). 